University of Nebraska - Lincoln

DigitalCommons@University of Nebraska - Lincoln

Faculty Papers and Publications in Animal

Science

Animal Science Department

2011

\title{
Heifer development systems: A comparison of grazing winter range or corn residue
}

D. M. Larson

University of Nebraska-Lincoln

Andrea S. Cupp

University of Nebraska-Lincoln, acupp2@unl.edu

Richard N. Funston

University of Nebraska-Lincoln, rfunston2@unl.edu

Follow this and additional works at: https://digitalcommons.unl.edu/animalscifacpub

Part of the Animal Sciences Commons

Larson, D. M.; Cupp, Andrea S.; and Funston, Richard N., "Heifer development systems: A comparison of grazing winter range or corn residue" (2011). Faculty Papers and Publications in Animal Science. 749. https://digitalcommons.unl.edu/animalscifacpub/749

This Article is brought to you for free and open access by the Animal Science Department at DigitalCommons@University of Nebraska - Lincoln. It has been accepted for inclusion in Faculty Papers and Publications in Animal Science by an authorized administrator of DigitalCommons@University of Nebraska - Lincoln. 


\title{
Heifer development systems: A comparison of grazing winter range or corn residue ${ }^{1}$
}

\author{
D. M. Larson, ${ }^{* \dagger}$ A. S. Cupp, $\dagger$ and R. N. Funston $* \dagger^{2}$ \\ *University of Nebraska West Central Research and Extension Center, North Platte 69101; \\ and $\dagger$ Department of Animal Sciences, University of Nebraska, Lincoln 68583
}

\begin{abstract}
Two experiments at 2 Nebraska locations evaluated effects of heifer development system on growth and pregnancy rate. In Exp. 1, heifers $(\mathrm{n}=270$, $\mathrm{BW}=225 \pm 2 \mathrm{~kg}$ ) grazed winter Sandhills range (WR) or west central Nebraska corn residue $(\mathrm{CR})$ with a supplement $\left(0.45 \mathrm{~kg}\right.$ /animal; $31 \% \mathrm{CP} ; 80 \mathrm{mg} \cdot$ animal $^{-1} \cdot \mathrm{d}^{-1}$ of monensin). In Exp. 2, heifers $(\mathrm{n}=180, \mathrm{BW}=262$ $\pm 3 \mathrm{~kg}$ ) grazed eastern Nebraska WR or CR with a supplement ( 0.45 to $0.90 \mathrm{~kg} / \mathrm{d} ; 31 \% \mathrm{CP} ; 80$ to 160 $\mathrm{mg} \cdot$ animal $^{-1} \cdot \mathrm{d}^{-1}$ of monensin). The CR heifers tended to have less $(P=0.10)$ ADG compared with WR heifers before breeding in Exp. 1; however, prebreeding ADG was similar $(P=0.77)$ in Exp. 2. Prebreeding BW, percentage of mature BW at breeding, and pregnancy determination $\mathrm{BW}$ were similar $(P \geq 0.14)$ for $\mathrm{CR}$ and WR in both experiments. Percentage of heifers puber-
\end{abstract}

tal at breeding, AI conception, and AI pregnancy rate (Exp. 2) and final pregnancy rate in both experiments were also similar $(P \geq 0.27)$ for $\mathrm{CR}$ and WR heifers. Precalving BW, percentage of calves born in the first $21 \mathrm{~d}$, calf birth date, calf birth BW, and dystocia score were all similar $(P \geq 0.21)$ for $\mathrm{CR}$ and WR heifers in both experiments. Cow BW at weaning, calf weaning BW, adjusted 205-d calf BW, and second season pregnancy rates were not affected $(P \geq 0.16)$ by treatment. Heifer development system did not affect $(P \geq 0.56)$ the cost of producing 1 pregnant heifer in Exp. 1 or 2 . Development on CR may reduce ADG before breeding, but did not affect pregnancy rate. Heifer development using CR or WR postweaning resulted in similar reproductive performance and development cost.

Key words: heifer development, supplement, winter grazing system

(C)2011 American Society of Animal Science. All rights reserved.

J. Anim. Sci. 2011. 89:2365-2372

doi:10.2527/jas.2010-3767

\section{INTRODUCTION}

Interest is increasing in alternative heifer development systems utilizing grazing and minimizing the use of harvested feedstuffs. However, dormant forages have reduced available nutrients (NRC, 2000) and may result in poorer animal performance, leading to reduced BW at breeding. Popular recommendations indicate heifers should reach $65 \%$ of mature BW before the first breeding season (Patterson et al., 1992). Recent data indicate heifers reaching $<55 \%$ of mature BW by breeding have similar reproductive ability to heavier counterparts (Funston and Deutscher, 2004; Martin

\footnotetext{
${ }^{1}$ A contribution of the University of Nebraska Agricultural Research Division, supported in part by funds provided through the Hatch Act. Mention of a trade name, proprietary product, or company name is for presentation clarity and does not imply endorsement by the authors or the University of Nebraska.

${ }^{2}$ Corresponding author: rfunston2@unl.edu

Received December 7, 2010.

Accepted March 28, 2011.
}

et al., 2008). Previous data also demonstrate moving heifer development from the dry lot in favor of grazing corn residue (CR) does not negatively influence pregnancy rate (Funston and Larson, 2010); however, BW at breeding is reduced and puberty is delayed. Winter range (WR) offers a similar source of standing winter forage for heifer development, but the effects are not well characterized. Therefore, these studies evaluated the effect of grazing CR compared with WR on firstservice conception rate, pregnancy rate, and first-calf production characteristics in beef heifers.

\section{MATERIALS AND METHODS}

The University of Nebraska-Lincoln Institutional Animal Care and Use Committee approved the procedures and facilities used in this experiment.

\section{Exp. 1}

A 3-yr study was conducted utilizing 270, Marchborn, composite Red Angus $\times$ Simmental nulliparous heifers $(\mathrm{BW}=225 \pm 2 \mathrm{~kg}$ initial $\mathrm{BW})$ from 3 pro- 
duction years at Gudmundsen Sandhills Laboratory (GSL), Whitman, NE, to compare postweaning WR development with $\mathrm{CR}$ winter grazing system during the same period. The upland range sites at GSL are dominated by little bluestem [Andropogon scoparius (Michx.) Nash], prairie sandreed [Calamovilfa longifolia (Hook.) Scribn.], sand bluestem (Andropogon hallii Hack.), sand lovegrass [Eragrostis trichoides (Nutt.) Wood], and blue grama [Bouteloua gracillis (H.K.B.) Lag. Ex Griffiths] (Adams et al., 1998). At branding the first week of May, spring-born, crossbred (Red Angus $\times$ Simmental) heifer calves were given a Mannheimia (Pasteurella) hemolytica type A1 vaccination (One Shot, Pfizer Animal Health, New York, NY) and a 7-way clostridial (Vision 7, Intervet, Millsboro, DE) vaccination. Before and at weaning, heifers received 2 doses of an infectious bovine rhinotracheitis/parainfluenza-3 virus/bovine respiratory syncytial virus/bovine viral diarrhea vaccine (PRISM 4, Ft. Dodge Animal Health, Overland Park, KS) $14 \mathrm{~d}$ apart. Weaned heifer calves were assigned randomly by initial $\mathrm{BW}$ to graze either CR or WR postweaning. Grazing treatments were initiated approximately $30 \mathrm{~d}$ after weaning beginning in midNovember and continuing through mid-February (93 d) each year. The upland WR site at GSL was described above. Heifers were shipped approximately $84 \mathrm{~km}$ to corn residue fields on November 15 and returned to GSL on February 15 each year. The corn fields were irrigated, planted in April, and harvested in October, with an average annual yield of $12,544 \mathrm{~kg} / \mathrm{ha}$. A daily supplement was offered (Table 1; $0.45 \mathrm{~kg} /$ animal; $31 \%$ $\mathrm{CP} ; 80 \mathrm{mg} \cdot$ animal $^{-1} \cdot \mathrm{d}^{-1}$ monensin; Rumensin, Elanco Animal Health, Indianapolis, IN) while grazing. Subsequently, all heifers grazed WR for $100 \mathrm{~d}$ before breeding with a daily supplement (Table $1 ; 0.45 \mathrm{~kg} /$ animal; $31 \%$ $\mathrm{CP} ; 80 \mathrm{mg} \cdot$ animal $^{-1} \cdot \mathrm{d}^{-1}$ of monensin). In addition to grazing, free-choice prairie hay was offered as weather conditions dictated in all years. Hay consumption averaged $1.8 \mathrm{~kg} / \mathrm{d}$ for CR and WR heifers.

At the beginning of the breeding season, heifers received an infectious bovine rhinotracheitis/parainfluenza-3 virus/bovine respiratory syncytial virus/bovine viral diarrhea (killed)/leptospirosis/vibriosis (Vira Shield 4+VL5, Novartis Animal Health, Larchwood, IA) vaccination. Estrus was synchronized with a single intramuscular (i.m.) injection of $\mathrm{PGF}_{2 \alpha}$ (PGF; Prostamate, Teva Animal Health Inc., St. Joseph, MO, or Lutalyse, Pfizer Animal Health) administered 108 h after bulls were grouped with heifers. Heifers were exposed to bulls for $45 \mathrm{~d}$ at a ratio of 1 bull to 25 heifers. Pregnancy determination was performed via transrectal ultrasonography approximately $45 \mathrm{~d}$ after completion of the breeding season. During the breeding season and until pregnancy determination, heifers grazed upland summer Sandhills range in a single group. After pregnancy determination, 42 nonpregnant heifers were culled. In addition, 81 heifers were sold after calving. However, only nonpregnant animals were included in the value of culled animals for economic analysis.
In the period between pregnancy determination and calving, pregnant heifers grazed upland Sandhills range during the fall until November 15 and CR during the winter with a supplement $(0.45 \mathrm{~kg} / \mathrm{d}, 31 \% \mathrm{CP}, 80$ $\mathrm{mg} \cdot$ animal $^{-1} \cdot \mathrm{d}^{-1}$ of monensin) until February 15 . Approximately 2 wk before calving, BW was measured. At calving, calf birth date (mean = March 9), birth BW, dystocia score, and sex were recorded. After calving, heifers consumed free-choice meadow hay until spring pasture was available for grazing. At branding the first week of May, all bull calves were castrated and all calves given a Mannheimia (Pasteurella) hemolytica type A1 vaccination (One Shot, Pfizer Animal Health) and a 7-way clostridial (Vision 7, Intervet) vaccination. Before and at weaning, calves received 2 doses of an infectious bovine rhinotracheitis/parainfluenza-3 virus/ bovine respiratory syncytial virus/bovine viral diarrhea vaccine (PRISM 4, Ft. Dodge Animal Health) 14 $\mathrm{d}$ apart. Also at weaning, BW was measured for cows and calves.

\section{Exp. 2}

Experiment 2 was conducted at the University of Nebraska Agricultural Research and Development Center (ARDC), Ithaca, over 2 production years. The pasture sites at the ARDC are dominated by smooth brome grass (Bromus inermis). At approximately $60 \mathrm{~d}$ of age, spring-born composite MARC III (1/4 Angus, 1/4 Hereford, 1/4 Red Poll, 1/4 Pinzgauer $\times$ Red Angus) heifer calves received an infectious bovine rhinotracheitis/parainfluenza-3 virus/bovine respiratory syncytial virus/bovine viral diarrhea type I and II vaccine (BoviShield 5, Pfizer Animal Health), a 7-way clostridial (One Shot Ultra 7, Pfizer Animal Health) vaccine, and a pinkeye vaccination (Alpha 7/MB1, Boehringer Ingelheim, Ridgefield, CT). Twenty-eight days before weaning, heifers were vaccinated against pinkeye (Alpha 7/ MB1, Boehringer Ingelheim) and a topical endectocide

Table 1. Composition of supplements offered to heifers grazing winter range or corn residue ${ }^{1}$

\begin{tabular}{lcc}
\hline \hline Item, DM \% & Exp. 1 & Exp. 2 \\
\hline DDGS $^{2}$ & 62 & 66 \\
Wheat middlings & 11 & - \\
Soybean hulls & - & 15 \\
Cottonseed meal & 9 & - \\
DCGF & 5 & - \\
Molasses & 5 & 2 \\
Urea & 2 & 3 \\
Pellet binder & - & 4 \\
Dicalcium phosphate & - & 5 \\
Salt & - & 3 \\
Vitamin and trace mineral package & 6 & 2 \\
\hline
\end{tabular}

${ }^{1}$ Exp. 1 conducted at the Gudmundsen Sandhills Laboratory, Whitman, NE; Exp. 2 conducted at the Agricultural Research and Development Center, Ithaca, NE.

${ }^{2}$ Dried distillers grain plus solubles.

${ }^{3}$ Dry corn gluten feed. 
was applied (Ivomec, Merial Ltd., Duluth, GA). Before and at weaning, heifers received 2 doses of an infectious bovine rhinotracheitis/parainfluenza-3 virus/bovine respiratory syncytial virus/bovine viral diarrhea type I and II vaccine (BoviShield 5, Pfizer Animal Health) and received a Haemophilus somnus and 7-way clostridial (Ultrabac7/Somnubac, Pfizer Animal Health) vaccine $28 \mathrm{~d}$ apart. In both years, heifers were weaned from their dams and grazed a common fall pasture with a supplement $(2.0 \mathrm{~kg} / \mathrm{d}, 10.5 \% \mathrm{CP}, \mathrm{DM}$ basis $)$ for 30 $\mathrm{d}$ before the initiation of treatments. Weaned heifer calves $(\mathrm{n}=180)$ were assigned randomly by initial BW $(262 \pm 2 \mathrm{~kg})$ to graze either CR or WR postweaning. Grazing treatments were initiated approximately $30 \mathrm{~d}$ after weaning beginning in mid November and continuing through mid February (119 d) each year. The WR grazed by the heifers was composed predominately of smooth brome grass (Bromus inermis). The CR heifers grazed fields adjacent to the WR pastures. The characteristics of the CR fields are similar to those described in Exp. 1. A daily supplement was offered (Table 1; 0.45 to $0.90 \mathrm{~kg} / \mathrm{d}, 31 \% \mathrm{CP}, 80$ to $160 \mathrm{mg} \cdot \mathrm{animal}^{-1} \cdot \mathrm{d}^{-1}$ of monensin) while animals were grazing. Subsequently, all heifers grazed WR for $100 \mathrm{~d}$ before breeding with a daily supplement (Table 1; $0.45 \mathrm{~kg} /$ animal, $31 \%$ CP, 80 $\mathrm{mg} \cdot$ animal $^{-1} \cdot \mathrm{d}^{-1}$ of monensin). In addition to grazing, free-choice brome hay $(13 \% \mathrm{CP}, 42 \% \mathrm{ADF}, \mathrm{DM}$ basis) was offered as weather conditions dictated in both years. Hay consumption averaged $4.2 \mathrm{~kg} / \mathrm{d}$ for CR heifers and $3.5 \mathrm{~kg} / \mathrm{d}$ for WR heifers.

Estrus was synchronized using 2 i.m. injections of PGF (Lutalyse, Pfizer Animal Health) administered 16 and $2 \mathrm{~d}$ before AI breeding. After the second PGF injection, estrus was detected by trained personnel at 3-h intervals during daylight hours for at least $5 \mathrm{~d}$. Because of adverse weather conditions in both years, the response to synchronization was poor (47\%). Thus, estrus was resynchronized in all nonresponding heifers $10 \mathrm{~d}$ after the second PGF injection with a third i.m. injection of PGF. Estrus detection was performed for an additional $5 \mathrm{~d}$ after the third PGF injection. Heifers were inseminated approximately $12 \mathrm{~h}$ after estrus was detected. Fourteen days after the second PGF injection, fertile bulls were grouped with heifers at a ratio of 1 bull to 50 heifers. Bulls remained with the heifers for $45 \mathrm{~d}$. Pregnancy to AI was determined via transrectal ultrasonography approximately $45 \mathrm{~d}$ after AI. Final pregnancy rate was determined via transrectal ultrasonography $45 \mathrm{~d}$ after bulls were removed.

After pregnancy determination, 25 nonpregnant heifers were sold. In addition, 54 pregnant heifers were sold as breeding animals to local producers to achieve an appropriate herd replacement rate. However, only nonpregnant heifers were included in the cull value for economic analysis. After pregnancy determination, all pregnant heifers were managed in a single group until calving. During this period, pregnant heifers grazed CR with a daily supplement $(1.2 \mathrm{~kg} / \mathrm{d}, 10.5 \% \mathrm{CP}, \mathrm{DM}$ basis). Free-choice prairie hay was provided as weather conditions dictated. Two weeks before calving, pregnant heifer BW was measured. At calving, calf birth date $($ mean $=$ March 19), birth BW, dystocia score, and sex were recorded. Between calving and the time when spring pasture was available for grazing, heifers consumed free-choice alfalfa/grass hay with a daily supplement $(1.2 \mathrm{~kg} / \mathrm{d}, 10.5 \% \mathrm{CP}, \mathrm{DM}$ basis $)$.

Approximately $65 \mathrm{~d}$ after calving, milk production was measured using a modified weigh-suckle-weigh technique (Boggs et al., 1980). At approximately $65 \mathrm{~d}$ of age, calves received an infectious bovine rhinotracheitis/parainfluenza-3 virus/bovine respiratory syncytial virus/bovine viral diarrhea type I and II vaccine (BoviShield 5, Pfizer Animal Health), a 7-way clostridial (One Shot Ultra 7, Pfizer Animal Health) vaccine, and pinkeye vaccination (Alpha 7/MB1, Boehringer Ingelheim). Twenty-eight days before weaning, calves were vaccinated against pinkeye (Alpha 7/MB1, Boehringer Ingelheim) and a topical endectocide was applied (Ivomec, Merial Ltd.). Before and at weaning, calves received 2 doses of an infectious bovine rhinotracheitis/parainfluenza-3 virus/bovine respiratory syncytial virus/bovine viral diarrhea type I and II vaccine (BoviShield 5, Pfizer Animal Health) and received a Haemophilus somnus and 7-way clostridial (Ultrabac7/ Somnubac; Pfizer Animal Health) vaccine $28 \mathrm{~d}$ apart. Cow and calf BW were also collected at weaning.

\section{$R I A$}

In both Exp. 1 and 2, 2 blood samples $(5 \mathrm{~mL}$ via coccygeal venipuncture) were collected at $10-\mathrm{d}$ intervals before the breeding season to determine pubertal status. Blood samples were stored at $4^{\circ} \mathrm{C}$ for serum separation by centrifugation $(2,500 \times g$ for $20 \mathrm{~min}$ at $4^{\circ} \mathrm{C}$ ) within $24 \mathrm{~h}$. Serum samples were stored at $-20^{\circ} \mathrm{C}$ for subsequent analysis. Serum progesterone concentrations were determined by direct solid-phase RIA (CoatA-Count, Siemens Medical Solutions Diagnostics, Los Angeles, CA) without extraction as described by Melvin et al. (1999). Intra- and interassay CV were 5.2 and $4.4 \%$, respectively. Progesterone concentration $>1 \mathrm{ng} /$ $\mathrm{mL}$ was interpreted to indicate ovarian luteal activity.

\section{Economic Evaluation}

An economic evaluation was conducted for Exp. 1 and 2. Winter grazing cost of WR and CR for a heifer calf was estimated to be one-half the cost of winter grazing for a mature cow, based upon heifer BW at weaning. Hay offered was valued at $\$ 83 / \mathrm{t}$, which was the purchase price. All nonfeeding costs, including veterinary charges, trucking, and yardage, were charged at an additional $\$ 0.50 /$ d. Summer grazing cost was estimated to be one-half the cost of summer grazing for a mature cow, based upon heifer BW before breeding. Heifer sale values at weaning and pregnancy de- 
termination were calculated from the Nebraska average price reported by USDA Agricultural Marketing Service for each individual date (USDA-AMS, 2008). Budgets evaluated the net returns from weaning until pregnancy determination. The net return from weaning until pregnancy determination was calculated using the formula developed by Feuz (1992). The total value of all nonpregnant, culled heifers was subtracted from the total development cost of all heifers. The total adjusted value of heifer development was then divided by the number of heifers exposed to arrive at the total cost of a heifer entered into the system. Finally, this value was divided by the pregnancy rate, providing the cost of developing 1 pregnant heifer.

\section{Statistical Analysis}

Because treatment was winter heifer development system, and heifers were managed either on a CR field or WR pasture and replicated 3 yr in Exp. 1 and 2 yr in Exp. 2, CR field or WR pasture were considered the experimental units for heifer performance and reproductive data. All data were tested for year $\times$ treatment interactions, and because none were found $(P>0.15)$, data regarding winter grazing system were combined across years for Exp. 1 and 2. The continuous data were analyzed with PROC MIXED (SAS Inst. Inc., Cary, NC). The binomial data were analyzed using PROC GLIMMIX of SAS.

\section{RESULTS}

\section{Exp. 1}

The heifer BW gain and BW data are displayed in Table 2. Although the predicted ADG (NRC, 2000) of heifers grazing $\mathrm{CR}$ was greater than heifers grazing WR, the opposite was found to be true in this study. Heifers grazing CR gained $0.10 \mathrm{~kg} / \mathrm{d}$ less $(P=0.06)$ and were $15 \mathrm{~kg}$ lighter $(P=0.04)$ after $\mathrm{CR}$ grazing than heifers grazing WR. Heifers grazing CR tended to gain less BW $(P=0.10)$ during the period between weaning and breeding but had similar $(P=0.14) \mathrm{BW}$ at breeding as WR heifers. Heifers originally grazing CR were approximately $52 \%$ of mature $\mathrm{BW}$ and those grazing WR approximately $55 \%$ of mature BW (544 $\mathrm{kg})$ at breeding $(P=0.14)$. Heifers grazing $\mathrm{CR}$ during the winter tended $(P=0.10)$ to compensate with greater summer ADG from the beginning of the breeding season to pregnancy determination compared with WR heifers, resulting in similar $(P=0.17) \mathrm{BW}$ at pregnancy determination and before calving $(P=0.42)$. There was a similar percentage of heifers reaching puberty before breeding in both winter systems $(P=0.27$; Table 3). Pregnancy rate after the first breeding season was also similar $(P=0.76)$ between treatment groups. The net cost of producing 1 pregnant heifer was similar $(P=0.56$; Table 4$)$ for WR- and CR-developed heifers.

Winter grazing system did not influence $(P \geq 0.51$; Table 5) percentage of heifers calving in the first $21 \mathrm{~d}$ of the calving season, calf birth date, calf birth BW, calving difficulty, dystocia score, or the percentage of male calves. Calf weaning BW and adjusted 205-d BW were similar $(P \geq 0.89)$ between calves from WR and CR heifers. Second-season pregnancy rate was also similar among cows previously grazing WR or $\mathrm{CR}(P=0.95$; Table 3).

Exp. 2

Heifer ADG and BW data for Exp. 2 are presented in Table 2. There were no differences $(P \geq 0.19)$ in

Table 2. Effects of grazing winter range or corn residue on heifer BW gain and BW ${ }^{1}$

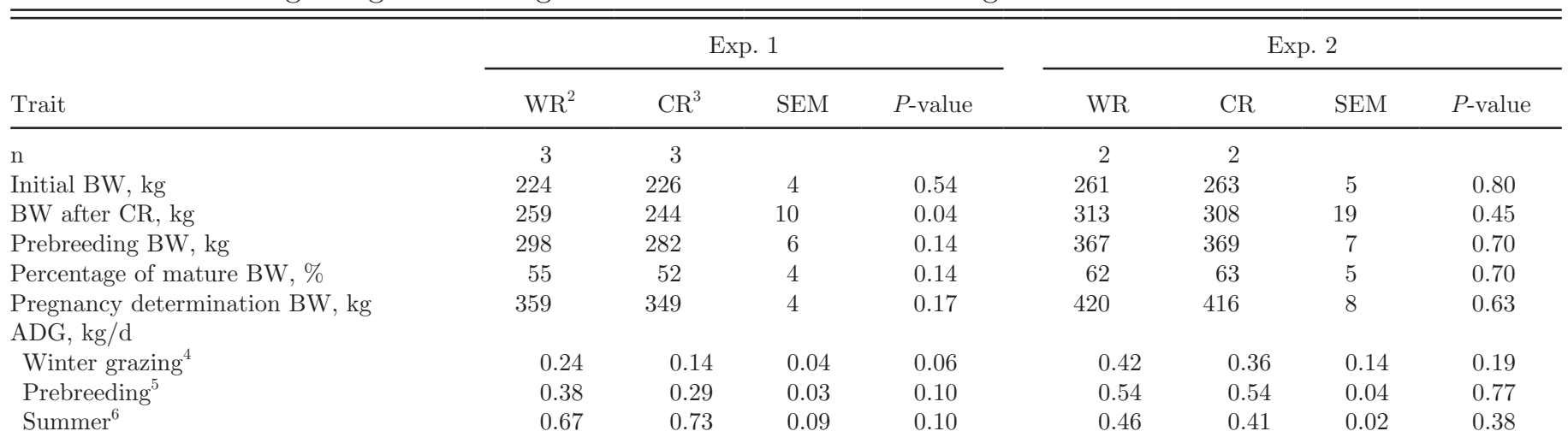

\footnotetext{
${ }^{1}$ Exp. 1 conducted at the Gudmundsen Sandhills Laboratory, Whitman, NE; Exp. 2 conducted at the Agricultural Research and Development Center, Ithaca, NE.

${ }^{2} \mathrm{WR}=$ heifers supplemented 3 times per week with the equivalent of $0.45 \mathrm{~kg} / \mathrm{d}$ of $31 \% \mathrm{CP}$ cubes (DM basis) and $1.8 \mathrm{~kg} / \mathrm{d}$ of hay (Exp. 1 ) and $3.5 \mathrm{~kg} / \mathrm{d}$ of hay (Exp. 2) postweaning while grazing winter range.

${ }^{3} \mathrm{CR}=$ heifers supplemented 3 times per week with the equivalent of $0.45 \mathrm{~kg} / \mathrm{d}$ of $31 \% \mathrm{CP}$ cubes (DM basis) and $1.8 \mathrm{~kg} / \mathrm{d}$ of hay (Exp. 1 ) and $4.2 \mathrm{~kg} / \mathrm{d}$ of hay (Exp. 2) postweaning while grazing corn residue.

${ }^{4} \mathrm{ADG}$ while heifers grazed WR or CR.

${ }^{5} \mathrm{ADG}$ in the period between weaning and the beginning of the breeding season.

${ }^{6} \mathrm{ADG}$ in the period between the first breeding service and pregnancy determination.
} 
Table 3. Effects of grazing winter range or corn residue on heifer reproduction ${ }^{1}$

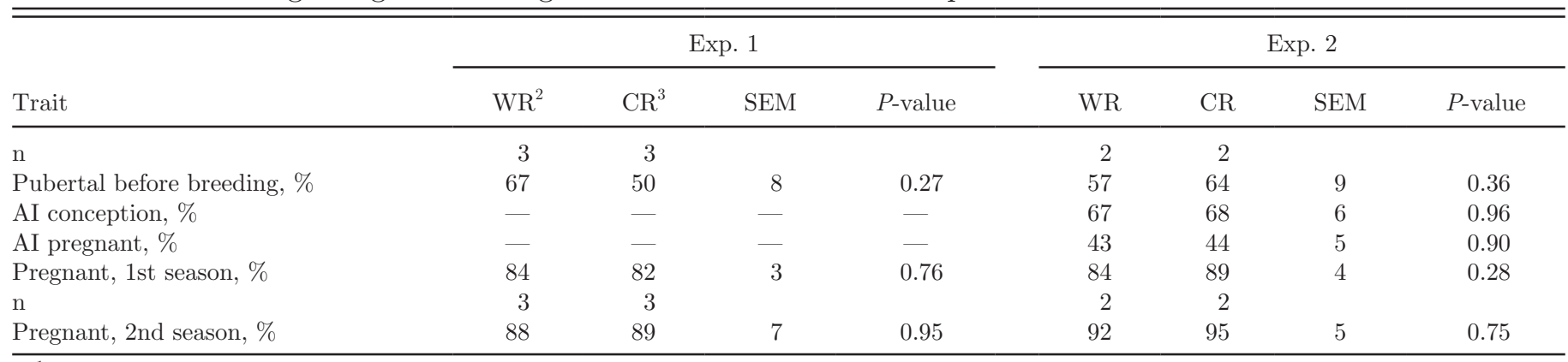

${ }^{1}$ Exp. 1 conducted at the Gudmundsen Sandhills Laboratory, Whitman, NE; Exp. 2 conducted at the Agricultural Research and Development Center, Ithaca, NE.

${ }^{2} \mathrm{WR}=$ heifers supplemented 3 times per week with the equivalent of $0.45 \mathrm{~kg} / \mathrm{d}$ of $31 \% \mathrm{CP}$ cubes (DM basis) and $1.8 \mathrm{~kg} / \mathrm{d}$ of hay (Exp. 1) and $3.5 \mathrm{~kg} / \mathrm{d}$ of hay (Exp. 2) postweaning while grazing winter range.

${ }^{3} \mathrm{CR}=$ heifers supplemented 3 times per week with the equivalent of $0.45 \mathrm{~kg} / \mathrm{d}$ of $31 \% \mathrm{CP}$ cubes (DM basis) and $1.8 \mathrm{~kg} / \mathrm{d}$ of hay (Exp. 1) and $4.2 \mathrm{~kg} / \mathrm{d}$ of hay (Exp. 2) postweaning while grazing corn residue.

any $\mathrm{ADG}$ or $\mathrm{BW}$ measurements taken from weaning to breeding. Heifers grazing $\mathrm{CR}$ were approximately $62 \%$ of mature BW and heifers grazing WR approximately $63 \%$ of mature BW $(590 \mathrm{~kg})$ before breeding $(P=0.70)$. Summer ADG between AI and pregnancy determination was similar $(P=0.38)$ for both treatment groups, resulting in similar $(P=0.63)$ heifer $\mathrm{BW}$ at pregnancy determination and before calving $(P=$ 0.40 ; Table 5). The percentage of heifers reaching puberty before AI was similar $(P=0.36$; Table 3$)$ between $\mathrm{CR}$ and WR heifer groups. The percentage of heifers conceiving to $\mathrm{AI}$ as a percentage of those exposed to AI $(P=0.96)$ and of those becoming pregnant to AI $(P=0.90)$ were also similar between treatment groups. Final pregnancy rate was also not different $(P=0.28)$ among CR and WR heifers. The net cost of producing 1 pregnant heifer was similar $(P=0.73$; Table 4$)$ for WR- and CR-developed heifers.

Calving data for Exp. 2 are presented in Table 5. Similar to Exp. 1, winter grazing system did not influence $(P \geq 0.30$; Table 5$)$ the percentage of heifers calving in the first $21 \mathrm{~d}$ of the season, calf birth date, calf birth BW, or the percentage of male calves. However, heifers grazing $\mathrm{CR}$ required $(P=0.04)$ more calving assistance than heifers developed on WR, despite a similar $(P=0.44)$ dystocia score. Twenty-four-hour milk production, measured approximately $65 \mathrm{~d}$ after calving, was similar $(P=0.93)$ for heifers grazing WR or CR during postweaning development. Calf weaning BW and adjusted 205-d BW were similar $(P \geq 0.37)$ between calves from CR and WR heifers. Second season pregnancy rate was also similar among cows previously grazing WR or CR $(P=0.75$; Table 3$)$.

\section{DISCUSSION}

Grazing standing winter forage is a common management practice in many beef cattle operations to reduce production costs. Winter range has historically been utilized as a source of winter forage for beef cows in the Nebraska Sandhills. Historical data indicate corn production in Nebraska increased by approximately $21 \%$ between 1997 and 2007 (USDA-NASS, 2008). Thus, CR available for grazing purposes increased as well. Previous research indicates $\mathrm{CR}$ and WR are acceptable sources of winter forage for mature, nonlactating beef cows in late gestation (Stalker et al., 2006, 2007; Martin et al., 2007; Larson et al., 2009; Funston et al., 2010). Recent research demonstrated CR utilization for

Table 4. Economics of grazing winter range or corn residue ${ }^{1}$

\begin{tabular}{|c|c|c|c|c|c|c|c|c|}
\hline \multirow[b]{2}{*}{ Trait } & \multicolumn{4}{|c|}{ Exp. 1} & \multicolumn{4}{|c|}{ Exp. 2} \\
\hline & $\mathrm{WR}^{2}$ & $\mathrm{CR}^{3}$ & SEM & $P$-value & WR & $\mathrm{CR}$ & SEM & $P$-value \\
\hline Total development cost,${ }^{4} \$ /$ heifer & 846 & 852 & 10.80 & 0.71 & 895 & 892 & 3.85 & 0.71 \\
\hline Cull heifer value, $\$ /$ heifer exposed & 133 & 143 & 16.90 & 0.70 & 155 & 102 & 34.85 & 0.39 \\
\hline Net cost of 1 pregnant heifer, $\$$ & 837 & 849 & 13.24 & 0.56 & 887 & 890 & 5.30 & 0.73 \\
\hline
\end{tabular}

${ }^{1}$ Exp. 1 conducted at the Gudmundsen Sandhills Laboratory, Whitman, NE; Exp. 2 conducted at the Agricultural Research and Development Center, Ithaca, NE.

${ }^{2} \mathrm{WR}=$ heifers supplemented 3 times per week with the equivalent of $0.45 \mathrm{~kg} / \mathrm{d}$ of $31 \% \mathrm{CP}$ cubes (DM basis) and $1.8 \mathrm{~kg} / \mathrm{d}$ of hay (Exp. 1) and $3.5 \mathrm{~kg} / \mathrm{d}$ of hay (Exp. 2) postweaning while grazing winter range.

${ }^{3} \mathrm{CR}=$ heifers supplemented 3 times per week with the equivalent of $0.45 \mathrm{~kg} / \mathrm{d}$ of $31 \% \mathrm{CP}$ cubes (DM basis) and $1.8 \mathrm{~kg} / \mathrm{d}$ of hay (Exp. 1 ) and $4.2 \mathrm{~kg} / \mathrm{d}$ of hay (Exp. 2) postweaning while grazing corn residue.

${ }^{4}$ Including all fixed and variable costs associated with interest, estrus synchronization, feed delivery, and breeding costs. 
Table 5. Effects of grazing winter range or corn residue on calf production ${ }^{1}$

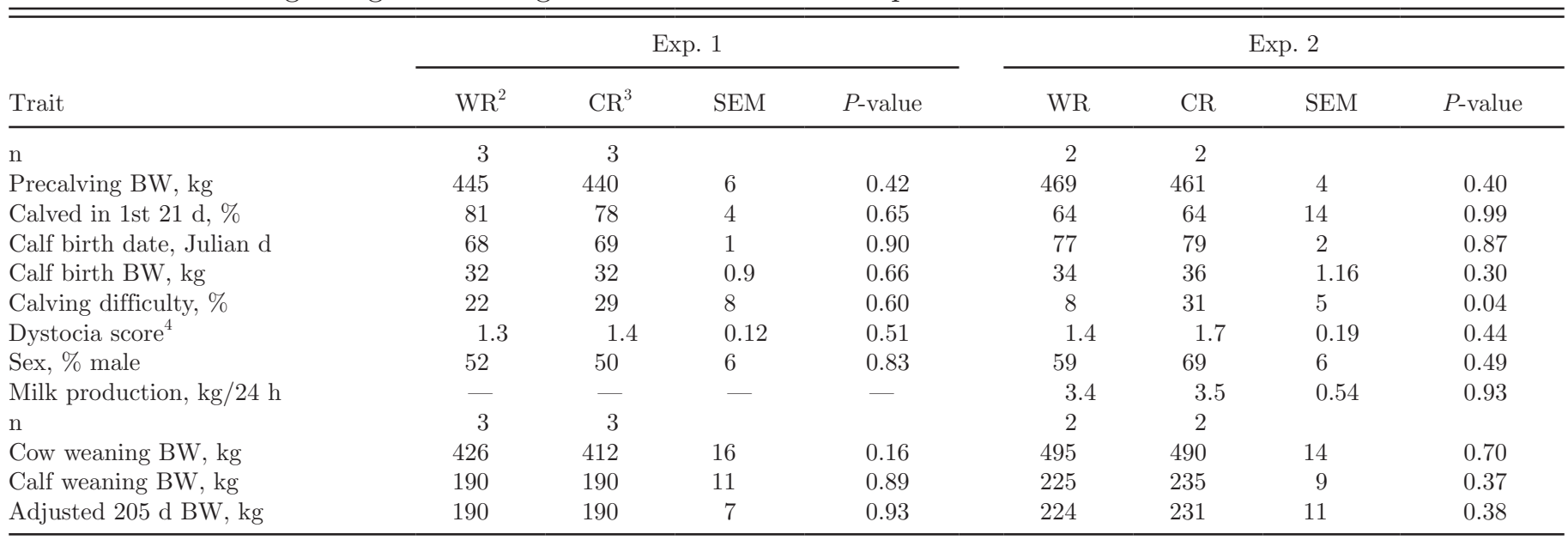

${ }^{1}$ Exp. 1 conducted at the Gudmundsen Sandhills Laboratory, Whitman, NE; Exp. 2 conducted at the Agricultural Research and Development Center, Ithaca, NE.

${ }^{2} \mathrm{WR}=$ heifers supplemented 3 times per week with the equivalent of $0.45 \mathrm{~kg} / \mathrm{d}$ of $31 \% \mathrm{CP}$ cubes (DM basis) and $1.8 \mathrm{~kg} / \mathrm{d}$ of hay (Exp. 1) and $3.5 \mathrm{~kg} / \mathrm{d}$ of hay (Exp. 2) postweaning while grazing winter range.

${ }^{3} \mathrm{CR}=$ heifers supplemented 3 times per week with the equivalent of $0.45 \mathrm{~kg} / \mathrm{d}$ of $31 \% \mathrm{CP}$ cubes (DM basis) and $1.8 \mathrm{~kg} / \mathrm{d}$ of hay (Exp. 1 ) and $4.2 \mathrm{~kg} / \mathrm{d}$ of hay (Exp. 2) postweaning while grazing corn residue.

${ }^{4}$ Dystocia score was defined as $1=$ no assistance, $2=$ easy pull, $3=$ hard pull, $4=$ cesarean section, $5=$ breach, and $6=$ dead.

most postweaning winter development was a suitable alternative to dry-lot feeding for replacement heifers (Funston and Larson, 2010). This work indicated heifers developed on CR gained less BW and weighed less before breeding compared with heifers developed in the dry lot. Grazing CR also reduced the percentage of heifers reaching puberty before breeding. However, after synchronization with melengestrol acetate/PGF, heifers grazing CR had slightly less AI pregnancy rates, but similar final pregnancy rates and decreased development costs.

Current data suggest heifers developed on CR tended to gain less BW than heifers on WR in Exp. 1; however, they have similar prebreeding BW, indicating a period of compensatory BW gain from CR removal to breeding. Different responses to grazing system between Exp. 1 and 2 may be related to snow cover. More hay was offered in Exp. 2 due to ice and snow cover preventing heifers from reaching CR. Hay was not routinely required in Exp. 1. Adverse weather conditions represent a risk with this system in areas prone to substantial snow cover. Prebreeding BW and percentage cycling before breeding were both numerically less for CR heifers in Exp. 1; however, pregnancy rates were similar among CR and WR heifers in both experiments. In the current study, heifers were only inseminated by AI in Exp. 2. The AI conception and pregnancy rates were similar, as may be expected due to the lack of difference in BW at breeding. As an alternative measure of early conception, we calculated the percentage of cows giving birth in the first $21 \mathrm{~d}$ of the season and found this to be similar in both treatment groups in both experiments. Perhaps the lack of effect on reproduction is linked to genetic change or compensatory ADG before or during the breeding season.
Earlier data suggested that heifers should reach approximately $65 \%$ of mature BW before the first breeding season (Patterson et al., 1992). This recommendation stems from data collected more than $18 \mathrm{yr}$ ago, indicating heifers reaching less than this target BW have reduced pregnancy rates (Wiltbank et al., 1965, 1985; Arije and Wiltbank, 1971; Short and Bellows, 1971; Patterson et al., 1991). However, more recent data indicate moderate nutrient restriction leading to reduced ADG postweaning does not influence replacement heifer reproductive success (Granger et al., 1990; Lalman et al., 1993; Buskirk et al., 1995, 1996; Lynch et al., 1997; Funston and Deutscher, 2004; Ciccioli et al., 2005; Gasser et al., 2006; Martin et al., 2008). Conclusions drawn from current research may differ from those of past research due to differences in cow herd genetics. A change in fertility over time, possibly due at least in part to genetics, is also supported by Cushman et al. (2007) who found 2-yr-old cows had a shorter postpartum interval than 3- or 4-yr-old cows. This challenges dogma that first-parity cows require a longer time to resume estrous cycles postpartum (Wiltbank and Cook, 1958).

The economic evaluation indicates similar feed costs between CR and WR treatments. As CR and WR heifers were of similar BW at treatment initiation by design, there was little difference in total heifer development cost. Pregnancy rates and subsequent cull heifer value were also similar in both Exp. 1 and 2, resulting in similar costs of producing 1 pregnant heifer. Previous data indicate lighter heifer BW at breeding reduces development cost (Funston and Deutscher, 2004; Martin et al., 2008; Funston and Larson, 2010). Using data collected during the 1980s, Feuz (2001) conducted an economic analysis to determine the optimal percentage 
of mature BW a heifer should reach before breeding. Despite a $9 \%$ reduction in pregnancy rate, Feuz (2001) found reducing percentage of mature BW at breeding from 65 to $55 \%$ reduced the net cost of developing 1 pregnant heifer by $\$ 19 /$ heifer.

Heifers developed on CR received more calving assistance than their counterparts developed on WR in Exp. 2. Although not significant, CR heifers had a numerical increase in both percentage male calves and calf birth BW, and numerically lighter BW at calving, which may have contributed to the increase in calving difficulty in Exp. 2. Apparent milk production was measured in Exp. 2 only. Milk production at $65 \mathrm{~d}$ postcalving was similar between treatments. There were no differences in calf weaning BW in Exp. 1 or 2. There were no differences in early conception or second-season final pregnancy rates among treatments in either Exp. 1 or 2 . These data agree with the analysis of heifer development systems to $<55 \%$ of mature BW presented by Funston and Deutscher (2004) and Martin et al. (2008).

Much of the recent research has been conducted in a dry-lot setting, and limited or no data exist comparing development systems utilizing standing forage. Producer interest in standing forage systems makes this comparison timely. Moreover, recent literature provides evidence of production goals shifting toward lower input systems. These data and previously published data from our group indicate developing heifers to $<55 \%$ of mature BW before breeding is adequate for reproduction, and producers can utilize alternative sources of standing winter forage as conditions allow. However, there is risk associated with grazing dormant forages in areas prone to snow cover. Conditions may require periodic feeding of harvested forage. Perhaps most importantly, this body of literature indicates a genetic change may have taken place allowing producers to reduce input cost by developing heifers to lighter BW before breeding.

\section{LITERATURE CITED}

Adams, D. C., R. T. Clark, P. E. Reece, and J. D. Volesky. 1998. Research and education for managing resources within the Nebraska Sandhills: The Gudmundsen Sandhills Laboratory. Rangelands 20:4-8.

Arije, G. F., and J. N. Wiltbank. 1971. Age and weight at puberty in Hereford heifers. J. Anim. Sci. 33:401-406.

Boggs, D. L., E. F. Smith, R. R. Schalles, B. E. Brant, L. R. Corah, and R. J. Pruitt. 1980. Effects of milk and forage intake on calf performance. J. Anim. Sci. 51:550-553.

Buskirk, D. D., D. B. Faulkner, W. L. Hurley, D. J. Kesler, F. A. Ireland, T. G. Nash, J. C. Castree, and J. L. Vicini. 1996. Growth, reproductive performance, mammary development, and milk production of beef heifers as influenced by prepubertal dietary energy and administration of bovine somatotropin. J. Anim. Sci. 74:2649-2662.

Buskirk, D. D., D. B. Faulkner, and F. A. Ireland. 1995. Increased postweaning gain of beef heifers enhances fertility and milk production. J. Anim. Sci. 73:937-946.

Ciccioli, N. H., S. L. Charles-Edwards, C. Floyd, R. P. Wettemann, H. T. Purvis, K. S. Lusby, G. W. Horn, and D. L. Lalman.
2005. Incidence of puberty in beef heifers fed high- or lowstarch diets for different periods before breeding. J. Anim. Sci. 83:2653-2662.

Cushman, R. A., M. F. Allan, R. M. Thallman, and L. V. Cundiff. 2007. Characterization of biological types of cattle (Cycle VII): Influence of postpartum interval and estrous cycle length on fertility. J. Anim. Sci. 85:2156-2162.

Feuz, D. M. 1992. Replacement beef heifer economics: when prices and reproductive performance are uncertain. American Society of Farm Managers and Rural Appraisers 56:61-66.

Feuz, D. M. 2001. Economics of young female management. In Proc. Range Beef Cow Symposium, Casper, WY. Univ. Wyoming, Laramie.

Funston, R. N., and G. H. Deutscher. 2004. Comparison of target breeding weight and breeding date for replacement beef heifers and effects on subsequent reproduction and calf performance. J. Anim. Sci. 82:3094-3099.

Funston, R. N., and D. M. Larson. 2010. Heifer development systems: Dry-lot feeding compared with grazing dormant winter forage. J. Anim. Sci. 89:1595-1602.

Funston, R. N., J. L. Martin, D. C. Adams, and D. M. Larson. 2010. Winter grazing system and supplementation of beef cows during late gestation influence heifer progeny. J. Anim. Sci. 88:4094-4101.

Gasser, C. L., E. J. Behlke, D. E. Grum, and M. L. Day. 2006. Effect of timing of feeding a high-concentrate diet on growth and attainment of puberty in early-weaned heifers. J. Anim. Sci. 84:3118-3122.

Granger, A. L., W. E. Wyatt, F. G. Hernbry, W. M. Craig, and D. L. Thompson Jr.. 1990. Effects of breed and wintering diet on heifer postweaning growth and development. J. Anim. Sci. 68:304-316.

Lalman, D. L., M. K. Peterson, R. P. Ansotegui, M. W. Tess, C. K. Clark, and J. S. Wiley. 1993. The effects of ruminally undegradable protein, propionic acid, and monensin on puberty and pregnancy in beef heifers. J. Anim. Sci. 71:2843-2852.

Larson, D. M., J. L. Martin, D. C. Adams, and R. N. Funston. 2009. Winter grazing system and supplementation during late gestation influence performance of beef cows and steer progeny. J. Anim. Sci. 87:1147-1155.

Lynch, J. M., G. C. Lamb, B. L. Miller, R. T. Brandt Jr., R. C. Cochran, and J. E. Minton. 1997. Influence of timing of gain on growth and reproductive performance of beef replacement heifers. J. Anim. Sci. 75:1715-1722.

Martin, J. L., K. W. Creighton, J. A. Musgrave, T. J. Klopfenstein, R. T. Clark, D. C. Adams, and R. N. Funston. 2008. Effect of prebreeding body weight or progestin exposure before breeding on beef heifer performance through the second breeding season. J. Anim. Sci. 86:451-459.

Martin, J. L., K. A. Vonnahme, D. C. Adams, G. P. Lardy, and R. N. Funston. 2007. Effects of dam nutrition on growth and reproductive performance of heifer calves. J. Anim. Sci. 85:841-847.

Melvin, E. J., B. R. Lindsey, J. Quintal-Franco, E. Zanella, K. E. Fike, C. P. Van Tassell, and J. E. Kinder. 1999. Circulating concentrations of estradiol, luteinizing hormone, and folliclestimulating hormone during waves of ovarian follicular development in prepubertal cattle. Biol. Reprod. 60:405-412.

NRC. 2000. Nutrient Requirements of Beef Cattle. 7th ed. Natl. Acad. Press, Washington, DC.

Patterson, D. J., L. R. Corah, J. R. Brethour, M. F. Spire, J. J. Higgins, G. H. Kiracofe, J. S. Stevenson, and D. D. Simms. 1991. Evaluation of reproductive traits in Bos taurus and Bos indicus crossbred heifers: Effects of post-weaning energy manipulation. J. Anim. Sci. 69:2349-2361.

Patterson, D. J., R. C. Perry, G. H. Kiracofe, R. A. Bellows, R. B. Staigmiller, and L. R. Corah. 1992. Management considerations in heifer development and puberty. J. Anim. Sci. 70:4018-4035.

Short, R. E., and R. A. Bellows. 1971. Relationships among weight gains, age at puberty and reproductive performance in heifers. J. Anim. Sci. 32:127-131. 
Stalker, L. A., D. C. Adams, T. J. Klopfenstein, D. M. Feuz, and R. N. Funston. 2006. Effects of pre- and postpartum nutrition on reproduction in spring calving cows and calf feedlot performance. J. Anim. Sci. 84:2582-2589.

Stalker, L. A., L. A. Ciminski, D. C. Adams, T. J. Klopfenstein, and R. T. Clark. 2007. Effects of weaning date and prepartum protein supplementation on cow performance and calf growth. Rangeland Ecol. Manag. 60:578-587.

USDA-AMS. 2008. Nebraska weekly feeder cattle auction summary. Accessed Jul. 22, 2008. http://www.ams.usda.gov/mnreports/ wh_ls795.txt.

USDA-NASS. 2008. Nebraska corn production and yield. Accessed Dec. 22, 2008. http://www.nass.usda.gov/ne/nebchart/cornprodyld.pdf.
Wiltbank, J. N., J. Bond, and E. J. Warwick. 1965. Influence of total feed and protein intake on reproductive performance of the beef female through the second calving. USDA Tech. Bull. 1314. Washington, DC.

Wiltbank, J. N., and A. C. Cook. 1958. The comparative reproductive performance of nursed cows and milked cows. J. Anim. Sci. 17:640-648.

Wiltbank, J. N., S. Roberts, J. Nix, and L. Rowden. 1985. Reproductive performance and profitability of heifers fed to weigh 272 or $318 \mathrm{~kg}$ at the start of the first breeding season. J. Anim. Sci. $60: 25-34$ 